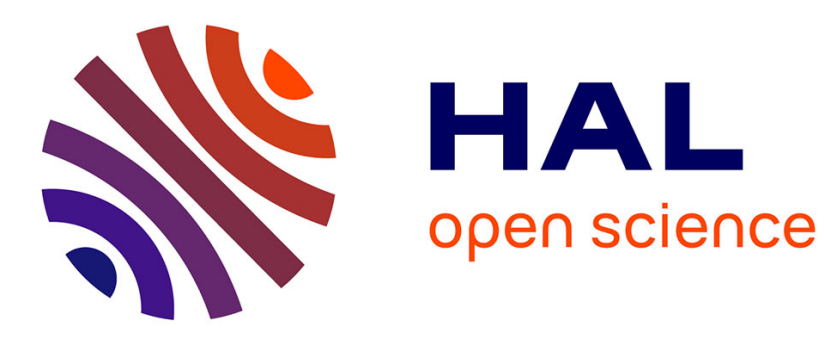

\title{
Stark Broadening in Compact Stars: Xe VI Lines
}

\author{
Milan S. Dimitrijević, Zoran Simić, Andjelka Kovačević, Aleksandar
}

Valjarević, Sylvie Sahal-Bréchot

\section{To cite this version:}

Milan S. Dimitrijević, Zoran Simić, Andjelka Kovačević, Aleksandar Valjarević, Sylvie Sahal-Bréchot. Stark Broadening in Compact Stars: Xe VI Lines. Journal of Astrophysics and Astronomy, 2015, pp.1-11. 10.1007/s12036-015-9352-y . hal-01258735

\section{HAL Id: hal-01258735 \\ https://hal.sorbonne-universite.fr/hal-01258735}

Submitted on 19 Jan 2016

HAL is a multi-disciplinary open access archive for the deposit and dissemination of scientific research documents, whether they are published or not. The documents may come from teaching and research institutions in France or abroad, or from public or private research centers.
L'archive ouverte pluridisciplinaire HAL, est destinée au dépôt et à la diffusion de documents scientifiques de niveau recherche, publiés ou non, émanant des établissements d'enseignement et de recherche français ou étrangers, des laboratoires publics ou privés. 


\title{
Stark Broadening in Compact Stars: Xe VI Lines
}

\author{
Milan S. Dimitrijević ${ }^{1,2,3}$ \\ Zoran Simić ${ }^{1}$ \\ Andjelka Kovačević ${ }^{4}$ \\ Aleksandar Valjarević ${ }^{5}$ \\ Sylvie Sahal-Bréchot ${ }^{2}$
}

Received —

\footnotetext{
${ }^{1}$ Astronomical Observatory, Volgina 7, 11060 Belgrade, Serbia

mdimitrijevic@aob.bg.ac.rs

${ }^{2}$ LERMA, Observatoire de Paris, PSL Research University, CNRS, Sorbonne Universities, UPMC Univ. Paris 06,

5 Place Jules Janssen, 92195 Meudon Cedex, France

${ }^{3}$ IHIS Techno Experts, Bežanijski put 23, 11080 Belgrade-Zemun, Serbia

${ }^{4}$ Department for Astronomy, Faculty for Mathematics, Studentski Trg 16, 11000 Belgrade, Serbia

${ }^{5}$ University of Kosovska Mitrovica, Faculty of Natural Sciences and Mathematics, Department of Geography, Ive Lole Ribara 29, 38220 Kosovska Mitrovica, Serbia
} 


\begin{abstract}
We will consider Stark broadening of non hydrogenic spectral lines in the impact approximation in compact stars: pre-white dwarf, white dwarf, and neutron star atmospheres. In order to show an example, Stark broadening parameters have been calculated, using the impact semiclassical perturbation approach, for four Xe VI spectral lines. Obtained results have been used to demonstrate the influence of Stark broadening in DA and DB white dwarf atmospheres.
\end{abstract}

Subject headings: Stark broadening; atomic data; white dwarfs, neutron stars, Xe VI 


\section{Introduction}

Compact stars like white dwarfs, pre-white dwarfs and neutron stars are particularly interesting for the applications of Stark broadening research, since in their atmospheres this broadening mechanism is dominant in comparison with other pressure broadening mechanisms and usually also in comparison with Doppler broadening. Such investigations are particularly stimulated by the development of satellite born telescopes which are providing high-resolution spectra of earlier inaccessible quality. For example, well-resolved line profiles of many white dwarfs and other hot and dense stars have been and will be provided by the Space Telescope Imaging Spectrograph (STIS), Cosmic Origins Spectrograph (COS) and Goddard High Resolution Spectrograph (GHRS), all three aboard the Hubble Space Telescope, as well as by Far Ultraviolet Spectroscopy Explorer (FUSE), the International Ultraviolet Explorer and others. According to Fontaine et al. (2008) the FUSE space mission provided a great number of high resolution spectra of elements such as: C, N, O, Si, S, P, Cl, Ne, Ar, V, Mn, Cr, Fe, Co, Ni, Ge, As, Se, Zr, Te, I, Pb and others in various ionization stages. Moreover, Werner et al. (2012) and Rauch et al. (2015) found Xe VI spectral lines in the spectrum of the DO white dwarf RE 0503-289 $\left(T_{\text {eff }}=70\right.$ 000 K, Dreizler \& Werner (1996)), obtained also by FUSE (Far Ultraviolet Spectroscopic Explorer).

Besides the astrophysical significance of Xe VI spectral lines, these lines are also of particular interest for experimental and theoretical studies (Kondo et al. 2008, 2009) of shock waves, driven by a compact pulse device at $40 \mathrm{~km} / \mathrm{s}$ into xenon gas. We note that Ryutov et al. (1999) stated that such experiments with high power lasers "contribute to

check the astrophysical computer codes and to bridge a gap between laboratory experiments and astronomical phenomena by scaling laws".

Here we will give a short review of Stark broadening in compact stars, and as an 
example, we will calculate Stark broadening parameters, line widths and shifts, due to collisions of Xe VI ions with electrons, protons and He III ions, by using impact semiclassical perturbation theory (Sahal-Bréchot 1969a,b), and we will use the obtained results to show the importance of Stark broadening of Xe VI lines for DA and DB white dwarfs.

\section{On the Stark broadening in compact stars}

Stark broadening data are of particular significance for hot and dense compact stars like white dwarfs, but also for neutron stars and for the post Asymptotic Giant Branch (AGB) stars, with terminated hydrogen and helium but not carbon burning. Such post AGB stars form a sequence of bright red giants, more luminous than the Red Giant Branch stars with electron-degenerate helium cores. The traditional division of white dwarfs is in the hydrogen-rich DA type, with broad hydrogen lines in their spectra and helium-rich DB white dwarfs, which spectra are characterized with neutral helium lines. White dwarfs with so low effective temperatures that only continuum is present in their spectra which show no helium or hydrogen lines represent DC type. Cool white dwarfs with traces of metals other than carbon are classified as DZ type. It is assumed that these metals are introduced by accretion from the matter from outside. They are denoted also as DAZ or DBZ type.

Now, the classification of helium-rich DB white dwarfs is more wider. They are divided in: DO type, with $40000 \mathrm{~K}<T_{\text {eff }}<120000 \mathrm{~K}$ (see e.g. Dreizler \& Werner (1996)), DB, with $12000 \mathrm{~K}<T_{\text {eff }}<40000 \mathrm{~K}$, and DQ, with $4000 \mathrm{~K}<T_{\text {eff }}<12000 \mathrm{~K}$, characterized by lines of carbon and $\mathrm{C}_{2}$ Swan band in the spectrum. The carbon lines in the spectra of DQ white dwarfs are present due to convection from the deeper layers (Koester 2010).

It is interesting to notice that the Zeeman broadening, not existing as a particular broadening mechanism in laboratory spectra, has been discovered in white dwarfs spectra 
(Schmidt et al. 1986).

For Stark broadening applications PG1159 stars (Werner et al. 1991), which are among the hottest stars, are also of great significance. They are hot hydrogen deficient pre-white dwarfs, with $100000 \mathrm{~K}<T_{\text {eff }}<140000 \mathrm{~K}$, with high surface gravity $(\log g=$ 7). Their atmospheres are composed of helium and carbon with a significant amount of oxygen $(\mathrm{C} / \mathrm{He}=0.5$ and $\mathrm{O} / \mathrm{He}=0.13)$ (Werner et al. 1991), and the main spectral lines in their spectra are of He II, C IV, O VI and N V.

Stark broadening influence on the spectral lines in DA and DB white dwarf atmospheres has been studied for Au II (Popović, Dimitrijević \& Tankosić 1999), Co III (Tankosić, Popović \& Dimitrijević 2003), Cd III (Milovanović et al. 2004), Cu III, Zn III, Se III (Simić et al. 2006), C II (Dufour et al. 2011; Larbi-Terzi et al. 2012), O II (Dufour et al. 2011), Cr II (Simić, Dimitrijević \& Sahal-Bréchot 2013) and Nb III (Simić, Dimitrijević \& Popović 2014a). Hamdi et al. (2008) analyzed Stark broadening of Si VI spectral lines in DO white dwarf spectra and Hamdi et al. (2014) Stark broadening of Ar III spectral lines in subdwarf B stars. It is shown that the influence of Stark broadening in the considered compact star spectra increases with $\log g$ and is dominant in broad atmospheric layers.

\section{Results and discussions}

The impact semiclassical perturbation formalism (Sahal-Bréchot 1969a,b), for the calculation of Stark broadening of non-hydrogenic, isolated spectral lines, used here, has been described with different innovations and optimizations in Sahal-Bréchot, Dimitrijević \& Ben Nessib (2014). We have calculated in the present paper full widths at half intensity maximum (FWHM) and shifts due to collisions with electrons, protons and He III ions, which are the main constituents of stellar atmospheres, for Xe VI $5 \mathrm{p}^{2} \mathrm{P}_{1 / 2}^{\mathrm{o}}-6 \mathrm{~s}{ }^{2} \mathrm{~S}_{1 / 2}, 5 \mathrm{p}$ 
${ }^{2} \mathrm{P}_{3 / 2}^{\mathrm{o}}-6 \mathrm{~s}{ }^{2} \mathrm{~S}_{1 / 2}, 6 \mathrm{~s}{ }^{2} \mathrm{~S}_{1 / 2}-6 \mathrm{p}{ }^{2} \mathrm{P}_{1 / 2}^{\mathrm{o}}$ and $6 \mathrm{~s}{ }^{2} \mathrm{~S}_{1 / 2}-6 \mathrm{p}{ }^{2} \mathrm{P}_{3 / 2}^{\mathrm{o}}$ lines. The needed energy levels have been taken from the compilation of Saloman (2004) (the original references for the set of atomic energy levels used in the present calculations, are Kaufman \& Sugar (1987); Tauheed, Joshi \& Pinnington (2012); Larsson et al. (1996); Wang et al. (1996, 1997) and Churilov \& Joshi (2000)) and the corresponding oscillator strengths have been calculated by using the method of Bates \& Damgaard (1949) and the tables of Oertel \& Shomo (1968). We note that more sophisticated calculations, using a Hartree-Fock method, exist in Biémont et al. (2005) and in Gallardo et al. (2015) for some oscillator strengths of the Xe VI. However, as we checked, it is not possible to obtain with them a complete set of oscillator strengths for all perturbing levels needed for a reliable semiclassical calculation. On the other hand we demonstrated in Dimitrijević \& Sahal-Bréchot (1994), that the best results are obtained if we use a complete consistent set of oscillator strengths and that a mixture of oscillator strengths obtained with various methods may result in worse agreement with experimental data for Stark broadening. The obtained results are presented in Table 1, for perturber densities from $10^{17} \mathrm{~cm}^{-3}$ to $10^{21} \mathrm{~cm}^{-3}$ and for temperatures from $20000 \mathrm{~K}$ to $500000 \mathrm{~K}$. For perturber densities lower than tabulated the dependence of Stark broadening parameters on density is linear.

By using the obtained results, the influence of Stark broadening on Xe VI lines in DA and DB white dwarf atmospheres has been investigated. Since the Doppler broadening is an important concurrent broadening mechanism, in order to estimate the influence of Stark broadening, Stark and Doppler widths have been compared in order to estimate the influence of Stark broadening. However, one should take into account that the Gauss distribution function for Doppler profile and the Lorentz distribution for Stark have different shapes, so that the Stark width may be smaller than the Doppler one, although the wings may still be influenced by Stark broadening. 
For the model atmosphere of DA and DB white dwarfs Wickramasinghe (1972) gives results in function of optical depth points at the standard wavelength $\lambda_{s}=5150 \AA\left(\tau_{5150}\right)$, so that here the same optical depth has been used. Electron-impact and Doppler widths are presented in Fig. 1 for the Xe VI $6 \mathrm{~s}^{2} \mathrm{~S}_{1 / 2}-6 \mathrm{p}{ }^{2} \mathrm{P}_{3 / 2}^{\mathrm{o}}(\lambda=2135.5 \AA)$ spectral line as a function of $\log \tau_{5150}$, for the atmospheric models (Wickramasinghe 1972) of DA and DB white dwarfs with surface gravity $\log g=8$, and $\mathrm{T}_{\text {eff }}=15000 \mathrm{~K}$. One can see in Fig. 1 that the broadening due to collisions with electrons is dominant in comparison with the concurrent Doppler broadening, for practically all relevant optical depths. One can see as well that for the same surface gravity and effective temperature, Stark broadening is considerably more effective for DB than for DA white dwarfs. Namely, in DA dwarfs the main source of electrons is the ionization of hydrogen and in DB double ionization of helium so that for the same temperature and surface gravity, the electron density is higher in DB white dwarf atmosphere and the corresponding electron-impact line width is larger than in the case of DA dwarf.

It is also interesting to compare the obtained Xe VI Stark broadening data, with the approximate formula for Stark widths of Cowley (1971). We calculated Stark widths $\mathrm{W}_{C}$, using Eq. (4) from Ziegler et al. (2012). For the temperature of $100000 \mathrm{~K}$ and an electron density of $10^{17} \mathrm{~cm}^{-3}$ we obtain for the line $447.5 \AA \mathrm{W}_{C}=0.000810 \AA$ while our semiclassical result $\mathrm{W}_{S C}$ is $0.00188 \AA$. For 481. $\AA$ line $\mathrm{W}_{C}=0.000937 \AA$ and $\mathrm{W}_{S C}=$ $0.00220 \AA$, for $2414.7 \AA$ line $\mathrm{W}_{C}=0.0312 \AA$ and $\mathrm{W}_{S C}=0.0631 \AA$, and for $2135.5 \AA$ line $\mathrm{W}_{C}=0.0255 \AA$ and $\mathrm{W}_{S C}=0.0500 \AA$. One can see that the approximate formula of Cowley (1971), even though it had a certain interest in the past, now is totally out-of-date, but it is still sometimes used in astrophysics, in spite of the fact that it largely underestimates Stark widths. 


\section{Conclusions}

We have calculated line widths and shifts due to collisions with electrons, protons, and He III ions for four spectral lines of Xe VI, using the impact semiclassical perturbation method. The calculated Stark broadening parameters have been introduced in the models of DA and DB white dwarf atmospheres and compared with Doppler broadening. Our new data confirm that Stark broadening is dominant in comparison with Doppler broadening and that Stark broadening is considerably more significant in DB white dwarf atmospheres than for DA white dwarfs with the same surface gravity and effective temperature.

The Stark broadening parameters for Xe VI spectral lines, shown in Table 1, will be implemented in computer readable form, in the STARK-B database (Sahal-Bréchot et al. 2015a,b), which is also a part of Virtual Atomic and Molecular Data Center - VAMDC (Dubernet et al. 2010; Rixon et al. 2011).

\section{Acknowledgements}

This work is a part of the project 176002 "Influence of collisional processes on astrophysical plasma line shapes" supported by the Ministry of Education, Science and Technological Development of Serbia. This work has also been supported by the Paris Observatory, the CNRS and the PNPS (Programme National de Physique Stellaire, INSU-CNRS).

Besides, this work took benefit of a fruitful discussion with Dr. J. Larour concerning the interest of Xe ionized lines observed in high power lasers experiments. This discussion took place at the annual 2015 scientific meeting of the Labex Plas@par, which is a Part of the Programme "Investissements d'avenir" under the reference ANR-11-IDEX-0004-02. 


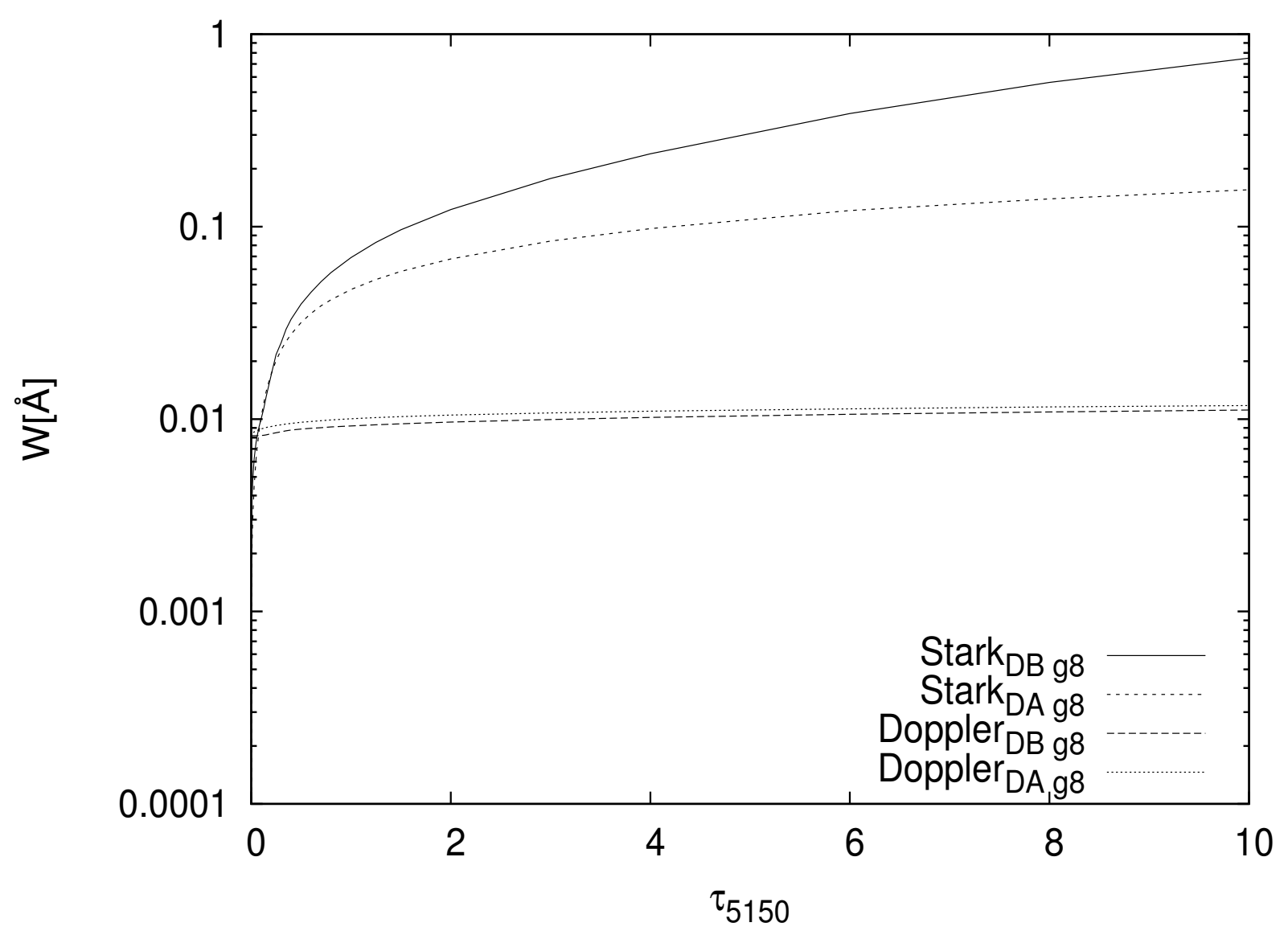

Fig. 1.- Electron-impact and Doppler widths for Xe VI $6 \mathrm{~s}{ }^{2} \mathrm{~S}_{1 / 2}-6 \mathrm{p}{ }^{2} \mathrm{P}_{3 / 2}^{\mathrm{o}}(\lambda=2135.5$ $\AA)$ spectral line as a function of the logarithm of optical depth at the standard wavelength $\lambda_{s}=5150 \AA\left(\tau_{5150}\right)$. Electron-impact and Doppler widths are shown for the atmospheric models (Wickramasinghe 1972) of DA and DB white dwarfs with surface gravity $\log g=8$, and $\mathrm{T}_{\text {eff }}=15000 \mathrm{~K}$. 
Table 1: This table gives electron-, proton-, and doubly charged helium-impact broadening parameters for Xe VI lines, for perturber densities (N) from $10^{17} \mathrm{~cm}^{-3}$ to $10^{21} \mathrm{~cm}^{-3}$ and temperatures from 20000 to $500000 \mathrm{~K}$. For perturber densities lower than tabulated the dependence of Stark broadening parameters on density is linear. Calculated wavelength of the transitions (in $\AA$ ) is also given. The notation is $\mathrm{W}_{e}$ : electron-impact full width at half maximum of intensity, $d_{e}$ : electron-impact shift, $\mathrm{W}_{p}$ : proton-impact full width at half maximum of intensity, $d_{p}$ : proton-impact shift, $\mathrm{W}_{\mathrm{He}^{++}}$: doubly charged helium ion-impact full width at half maximum of intensity, $d_{\mathrm{He}^{++}}$: doubly charged helium ion-impact shift. The parameter C, when divided with the corresponding Stark width, gives an estimate for the maximal pertuber density for which the line may be treated as isolated. A positive shift is towards the red.

\begin{tabular}{|c|c|c|c|c|c|c|c|}
\hline \multirow[t]{2}{*}{ Transition } & $\mathrm{T}$ & $\mathrm{W}_{e}$ & $\mathrm{~d}_{e}$ & $\mathrm{~W}_{p}$ & $\mathrm{~d}_{p}$ & $\mathrm{~W}_{\mathrm{He}^{++}}$ & $\mathrm{d}_{H e^{++}}$ \\
\hline & {$[\mathrm{K}]$} & {$[\AA]$} & {$[\AA]$} & {$[\AA]$} & {$[\AA]$} & {$[\AA]$} & {$[\AA]$} \\
\hline \multicolumn{8}{|l|}{$\mathrm{N}=10^{17} \mathrm{~cm}^{-3}$} \\
\hline $5 p^{2} \mathrm{P}^{o}-6 \mathrm{~s}^{2} \mathrm{~S}$ & 20000. & $0.460 \mathrm{E}-02$ & $0.630 \mathrm{E}-05$ & $0.345 \mathrm{E}-05$ & $0.296 \mathrm{E}-04$ & $0.681 \mathrm{E}-05$ & $0.532 \mathrm{E}-04$ \\
\hline $1 / 2-1 / 2$ & 50000. & $0.263 \mathrm{E}-02$ & $0.228 \mathrm{E}-03$ & $0.262 \mathrm{E}-04$ & $0.738 \mathrm{E}-04$ & $0.522 \mathrm{E}-04$ & $0.141 \mathrm{E}-03$ \\
\hline $447.5 \AA$ & 100000 . & $0.188 \mathrm{E}-02$ & $0.211 \mathrm{E}-03$ & $0.723 \mathrm{E}-04$ & $0.117 \mathrm{E}-03$ & $0.144 \mathrm{E}-03$ & $0.231 \mathrm{E}-03$ \\
\hline \multirow{3}{*}{$\mathrm{C}=0.83 \mathrm{E}+19$} & 200000 & $0.141 \mathrm{E}-02$ & $0.228 \mathrm{E}-03$ & $0.127 \mathrm{E}-03$ & $0.160 \mathrm{E}-03$ & $0.254 \mathrm{E}-03$ & $0.321 \mathrm{E}-03$ \\
\hline & 300000 . & $0.122 \mathrm{E}-02$ & $0.238 \mathrm{E}-03$ & $0.166 \mathrm{E}-03$ & 0.179E-03 & $0.332 \mathrm{E}-03$ & $0.359 \mathrm{E}-03$ \\
\hline & 500000 & $0.104 \mathrm{E}-02$ & $0.219 \mathrm{E}-03$ & $0.203 \mathrm{E}-03$ & $0.205 \mathrm{E}-03$ & $0.409 \mathrm{E}-03$ & $0.412 \mathrm{E}-03$ \\
\hline $5 \mathrm{p}^{2} \mathrm{P}^{\mathrm{o}}-6 \mathrm{~s}^{2} \mathrm{~S}$ & 20000. & $0.513 \mathrm{E}-02$ & $0.108 \mathrm{E}-04$ & $0.422 \mathrm{E}-05$ & $0.340 \mathrm{E}-04$ & $0.833 \mathrm{E}-05$ & $0.612 \mathrm{E}-04$ \\
\hline $3 / 2-1 / 2$ & 50000. & $0.304 \mathrm{E}-02$ & $0.260 \mathrm{E}-03$ & $0.308 \mathrm{E}-04$ & $0.849 \mathrm{E}-04$ & $0.614 \mathrm{E}-04$ & $0.163 \mathrm{E}-03$ \\
\hline $481 \AA$ & 100000 & $0.220 \mathrm{E}-02$ & $0.241 \mathrm{E}-03$ & $0.841 \mathrm{E}-04$ & $0.134 \mathrm{E}-03$ & $0.168 \mathrm{E}-03$ & $0.266 \mathrm{E}-031$ \\
\hline \multirow[t]{3}{*}{$\mathrm{C}=0.96 \mathrm{E}+19$} & 200000 . & $0.165 \mathrm{E}-02$ & $0.261 \mathrm{E}-03$ & $0.148 \mathrm{E}-03$ & $0.185 \mathrm{E}-03$ & $0.295 \mathrm{E}-03$ & $0.370 \mathrm{E}-03$ \\
\hline & 300000 . & $0.142 \mathrm{E}-02$ & $0.272 \mathrm{E}-03$ & $0.192 \mathrm{E}-03$ & $0.206 \mathrm{E}-03$ & $0.384 \mathrm{E}-03$ & $0.413 \mathrm{E}-03$ \\
\hline & 500000 & $0.122 \mathrm{E}-02$ & $0.250 \mathrm{E}-03$ & $0.236 \mathrm{E}-03$ & $0.236 \mathrm{E}-03$ & $0.473 \mathrm{E}-03$ & $0.475 \mathrm{E}-03$ \\
\hline
\end{tabular}


Table 1: Continued

\begin{tabular}{|c|c|c|c|c|c|c|c|}
\hline tion & $\begin{array}{r}\mathrm{T} \\
{[\mathrm{K}]} \\
\end{array}$ & $\begin{array}{l}\mathrm{W}_{e} \\
{[\AA]} \\
\end{array}$ & $\begin{array}{r}\mathrm{d}_{e} \\
{[\AA]} \\
\end{array}$ & $\begin{array}{l}\mathrm{W}_{p} \\
{[\AA]} \\
\end{array}$ & $\begin{array}{r}\mathrm{d}_{p} \\
{[\AA]} \\
\end{array}$ & $\begin{array}{r}\mathrm{W}_{H e^{++}} \\
{[\AA]}\end{array}$ & $\begin{array}{r}\mathrm{d}_{H e^{++}} \\
{[\AA]} \\
\end{array}$ \\
\hline $6 \mathrm{~s}^{2} \mathrm{~S}-6 \mathrm{p}{ }^{2} \mathrm{P}^{\circ}$ & 20000 & 0.135 & $0.944 \mathrm{E}-03$ & $0.822 \mathrm{E}-03$ & $-0.452 \mathrm{E}-03$ & $0.161 \mathrm{E}-02$ & $-0.813 \mathrm{E}-03$ \\
\hline $1 / 2-1 / 2$ & 50000 & $0.861 \mathrm{E}-01$ & $-0.265 \mathrm{E}-02$ & $0.247 \mathrm{E}-02$ & $-0.118 \mathrm{E}-02$ & $0.491 \mathrm{E}-02$ & $-0.227 \mathrm{E}-02$ \\
\hline $2414.7 \AA$ & 100000 & $0.631 \mathrm{E}-01$ & $-0.248 \mathrm{E}-02$ & $0.418 \mathrm{E}-02$ & $-0.200 \mathrm{E}-02$ & 0.832E-02 & $-0.397 \mathrm{E}-02$ \\
\hline \multirow[t]{3}{*}{$\mathrm{C}=0.24 \mathrm{E}+21$} & 200000 & $0.481 \mathrm{E}-01$ & $-0.312 \mathrm{E}-02$ & $0.592 \mathrm{E}-02$ & $-0.283 \mathrm{E}-02$ & $0.118 \mathrm{E}-01$ & $-0.567 \mathrm{E}-02$ \\
\hline & 300000. & 0.419E-01 & $-0.317 \mathrm{E}-02$ & $0.652 \mathrm{E}-02$ & $-0.333 \mathrm{E}-02$ & $0.130 \mathrm{E}-01$ & $-0.667 \mathrm{E}-02$ \\
\hline & 500000. & $0.360 \mathrm{E}-01$ & $-0.290 \mathrm{E}-02$ & $0.733 \mathrm{E}-02$ & $-0.379 \mathrm{E}-02$ & $0.147 \mathrm{E}-01$ & $-0.761 \mathrm{E}-02$ \\
\hline $6{ }^{2} \mathrm{~S}-6 \mathrm{p}{ }^{2} \mathrm{P}^{o}$ & 20000 & 0.107 & $0.712 \mathrm{E}-03$ & 0.693E-03 & $-0.305 \mathrm{E}-03$ & $0.136 \mathrm{E}-02$ & $-0.549 \mathrm{E}-03$ \\
\hline $1 / 2-3 / 2$ & 50000 & 0.683E-01 & $-0.179 \mathrm{E}-02$ & $0.205 \mathrm{E}-02$ & $-0.801 \mathrm{E}-03$ & $0.406 \mathrm{E}-02$ & $-0.154 \mathrm{E}-02$ \\
\hline $2135.5 \AA$ & 100000. & $0.500 \mathrm{E}-01$ & $-0.166 \mathrm{E}-02$ & $0.340 \mathrm{E}-02$ & $-0.138 \mathrm{E}-02$ & $0.678 \mathrm{E}-02$ & $-0.273 \mathrm{E}-02$ \\
\hline \multirow[t]{3}{*}{$\mathrm{C}=0.19 \mathrm{E}+21$} & 200000 & $0.381 \mathrm{E}-01$ & $-0.212 \mathrm{E}-02$ & $0.477 \mathrm{E}-02$ & $-0.197 \mathrm{E}-02$ & $0.952 \mathrm{E}-02$ & $-0.395 \mathrm{E}-02$ \\
\hline & 300000. & $0.332 \mathrm{E}-01$ & $-0.215 \mathrm{E}-02$ & $0.521 \mathrm{E}-02$ & $-0.234 \mathrm{E}-02$ & $0.104 \mathrm{E}-01$ & $-0.468 \mathrm{E}-02$ \\
\hline & 500000 & $0.286 \mathrm{E}-01$ & $-0.196 \mathrm{E}-02$ & $0.582 \mathrm{E}-02$ & $-0.268 \mathrm{E}-02$ & $0.116 \mathrm{E}-01$ & $-0.539 \mathrm{E}-02$ \\
\hline \multicolumn{8}{|l|}{$\mathrm{N}=10^{18} \mathrm{~cm}^{-3}$} \\
\hline $5 \mathrm{p}^{2} \mathrm{P}^{\mathrm{o}}-6 \mathrm{~s}^{2} \mathrm{~S}$ & 20000 & $0.453 \mathrm{E}-01$ & $-0.351 \mathrm{E}-03$ & 0.339E-04 & $0.233 \mathrm{E}-03$ & $0.623 \mathrm{E}-04$ & $0.321 \mathrm{E}-03$ \\
\hline $1 / 2-1 / 2$ & 50000 & $0.262 \mathrm{E}-01$ & $0.220 \mathrm{E}-02$ & $0.261 \mathrm{E}-03$ & $0.681 \mathrm{E}-03$ & $0.520 \mathrm{E}-03$ & $0.124 \mathrm{E}-02$ \\
\hline $447.5 \AA$ & 100000. & $0.188 \mathrm{E}-01$ & $0.207 \mathrm{E}-02$ & 0.723E-03 & $0.112 \mathrm{E}-02$ & $0.144 \mathrm{E}-02$ & $0.215 \mathrm{E}-02$ \\
\hline \multirow[t]{3}{*}{$\mathrm{C}=0.83 \mathrm{E}+20$} & 200000 & $0.141 \mathrm{E}-01$ & $0.227 \mathrm{E}-02$ & $0.127 \mathrm{E}-02$ & $0.160 \mathrm{E}-02$ & $0.255 \mathrm{E}-02$ & $0.314 \mathrm{E}-02$ \\
\hline & 300000. & $0.122 \mathrm{E}-01$ & $0.235 \mathrm{E}-02$ & $0.166 \mathrm{E}-02$ & $0.179 \mathrm{E}-02$ & $0.332 \mathrm{E}-02$ & $0.353 \mathrm{E}-02$ \\
\hline & 500000. & $0.104 \mathrm{E}-01$ & $0.218 \mathrm{E}-02$ & 0.203E-02 & $0.205 \mathrm{E}-02$ & 0.409E-02 & $0.411 \mathrm{E}-02$ \\
\hline
\end{tabular}


Table 1: Continued

\begin{tabular}{crrrrrrr}
\hline Transition & $\mathrm{T}$ & $\mathrm{W}_{e}$ & $\mathrm{~d}_{e}$ & $\mathrm{~W}_{p}$ & $\mathrm{~d}_{p}$ & $\mathrm{~W}_{H e^{++}}$ & $\mathrm{d}_{H e^{++}}$ \\
& {$[\mathrm{K}]$} & {$[\AA]$} & {$[\AA]$} & {$[\AA]$} & {$[\AA]$} & {$[\AA]$} & {$[\AA]$} \\
\hline $5 \mathrm{p}^{2} \mathrm{P}^{\circ}-6 \mathrm{~s}^{2} \mathrm{~S}$ & 20000. & $0.526 \mathrm{E}-01$ & $-0.357 \mathrm{E}-03$ & $0.414 \mathrm{E}-04$ & $0.268 \mathrm{E}-03$ & $0.757 \mathrm{E}-04$ & $0.369 \mathrm{E}-03$ \\
$3 / 2-1 / 2$ & 50000. & $0.305 \mathrm{E}-01$ & $0.251 \mathrm{E}-02$ & $0.307 \mathrm{E}-03$ & $0.784 \mathrm{E}-03$ & $0.611 \mathrm{E}-03$ & $0.143 \mathrm{E}-02$ \\
$481.0 \AA$ & 100000. & $0.220 \mathrm{E}-01$ & $0.236 \mathrm{E}-02$ & $0.841 \mathrm{E}-03$ & $0.130 \mathrm{E}-02$ & $0.168 \mathrm{E}-02$ & $0.247 \mathrm{E}-02$ \\
$\mathrm{C}=0.96 \mathrm{E}+20$ & 200000. & $0.165 \mathrm{E}-01$ & $0.259 \mathrm{E}-02$ & $0.148 \mathrm{E}-02$ & $0.184 \mathrm{E}-02$ & $0.295 \mathrm{E}-02$ & $0.362 \mathrm{E}-02$ \\
& 300000. & $0.143 \mathrm{E}-01$ & $0.269 \mathrm{E}-02$ & $0.192 \mathrm{E}-02$ & $0.206 \mathrm{E}-02$ & $0.384 \mathrm{E}-02$ & $0.407 \mathrm{E}-02$ \\
& 500000. & $0.122 \mathrm{E}-01$ & $0.250 \mathrm{E}-02$ & $0.236 \mathrm{E}-02$ & $0.236 \mathrm{E}-02$ & $0.473 \mathrm{E}-02$ & $0.474 \mathrm{E}-02$ \\
\hline $6 \mathrm{~s}{ }^{2} \mathrm{~S}-6 \mathrm{p}{ }^{2} \mathrm{P}^{\circ}$ & 20000. & 1.35 & $0.150 \mathrm{E}-01$ & $0.789 \mathrm{E}-02$ & $-0.357 \mathrm{E}-02$ & $0.133 \mathrm{E}-01$ & $-0.492 \mathrm{E}-02$ \\
$1 / 2-1 / 2$ & 50000. & 0.861 & $-0.253 \mathrm{E}-01$ & $0.246 \mathrm{E}-01$ & $-0.109 \mathrm{E}-01$ & $0.483 \mathrm{E}-01$ & $-0.200 \mathrm{E}-01$ \\
$2414.7 \AA$ & 100000. & 0.631 & $-0.241 \mathrm{E}-01$ & $0.417 \mathrm{E}-01$ & $-0.194 \mathrm{E}-01$ & $0.829 \mathrm{E}-01$ & $-0.373 \mathrm{E}-01$ \\
$\mathrm{C}=0.24 \mathrm{E}+22$ & 200000. & 0.481 & $-0.310 \mathrm{E}-01$ & $0.592 \mathrm{E}-01$ & $-0.282 \mathrm{E}-01$ & 0.118 & $-0.557 \mathrm{E}-01$ \\
& 300000. & 0.419 & $-0.314 \mathrm{E}-01$ & $0.652 \mathrm{E}-01$ & $-0.332 \mathrm{E}-01$ & 0.130 & $-0.659 \mathrm{E}-01$ \\
& 500000. & 0.360 & $-0.289 \mathrm{E}-01$ & $0.733 \mathrm{E}-01$ & $-0.379 \mathrm{E}-01$ & 0.147 & $-0.759 \mathrm{E}-01$ \\
\hline $6 \mathrm{~s}{ }^{2} \mathrm{~S}-6 \mathrm{p}{ }^{2} \mathrm{P}^{\circ}$ & 20000. & 1.07 & $0.109 \mathrm{E}-01$ & $0.665 \mathrm{E}-02$ & $-0.241 \mathrm{E}-02$ & $0.112 \mathrm{E}-01$ & $-0.332 \mathrm{E}-02$ \\
$1 / 2-3 / 2$ & 50000. & 0.683 & $-0.171 \mathrm{E}-01$ & $0.204 \mathrm{E}-01$ & $-0.744 \mathrm{E}-02$ & $0.399 \mathrm{E}-01$ & $-0.136 \mathrm{E}-01$ \\
$2135.5 \AA$ & 100000. & 0.500 & $-0.160 \mathrm{E}-01$ & $0.340 \mathrm{E}-01$ & $-0.134 \mathrm{E}-01$ & $0.675 \mathrm{E}-01$ & $-0.257 \mathrm{E}-01$ \\
$\mathrm{C}=0.19 \mathrm{E}+22$ & 200000. & 0.381 & $-0.210 \mathrm{E}-01$ & $0.477 \mathrm{E}-01$ & $-0.197 \mathrm{E}-01$ & $0.951 \mathrm{E}-01$ & $-0.388 \mathrm{E}-01$ \\
& 300000. & 0.332 & $-0.213 \mathrm{E}-01$ & $0.521 \mathrm{E}-01$ & $-0.233 \mathrm{E}-01$ & 0.104 & $-0.463 \mathrm{E}-01$ \\
& 500000. & 0.286 & $-0.196 \mathrm{E}-01$ & $0.582 \mathrm{E}-01$ & $-0.268 \mathrm{E}-01$ & 0.116 & $-0.538 \mathrm{E}-01$ \\
\hline
\end{tabular}


Table 1: Continued

\begin{tabular}{|c|c|c|c|c|c|c|c|}
\hline \multirow[t]{2}{*}{ Transition } & $\mathrm{T}$ & $\mathrm{W}_{e}$ & $\mathrm{~d}_{e}$ & $\mathrm{~W}_{p}$ & $\mathrm{~d}_{p}$ & $\mathrm{~W}_{H e^{++}}$ & $\mathrm{d}_{H e^{++}}$ \\
\hline & {$[\mathrm{K}]$} & {$[\AA]$} & {$[\AA]$} & {$[\AA]$} & {$[\AA]$} & {$[\AA]$} & {$[\AA]$} \\
\hline \multicolumn{8}{|l|}{$\mathrm{N}=10^{19} \mathrm{~cm}^{-3}$} \\
\hline $5 p^{2} \mathrm{P}^{o}-6 \mathrm{~s}^{2} \mathrm{~S}$ & 20000 & $* 0.452$ & *-0.705E-02 & $* 0.285 \mathrm{E}-03$ & $* 0.106 \mathrm{E}-02$ & $* 0.355 \mathrm{E}-03$ & $* 0.643 \mathrm{E}-03$ \\
\hline $1 / 2-1 / 2$ & 50000 & 0.262 & $0.202 \mathrm{E}-01$ & $0.260 \mathrm{E}-02$ & $0.551 \mathrm{E}-02$ & $* 0.496 \mathrm{E}-02$ & $* 0.764 \mathrm{E}-02$ \\
\hline $447.5 \AA$ & 100000 & 0.188 & $0.197 \mathrm{E}-01$ & $0.722 \mathrm{E}-02$ & $0.101 \mathrm{E}-01$ & $* 0.144 \mathrm{E}-01$ & $* 0.176 \mathrm{E}-01$ \\
\hline \multirow[t]{3}{*}{$\mathrm{C}=0.83 \mathrm{E}+21$} & 200000 & 0.141 & $0.219 \mathrm{E}-01$ & $0.127 \mathrm{E}-01$ & $0.151 \mathrm{E}-01$ & $*_{0} 0.253 \mathrm{E}-01$ & $* 0.279 \mathrm{E}-01$ \\
\hline & 300000. & 0.122 & $0.228 \mathrm{E}-01$ & $0.166 \mathrm{E}-01$ & $0.174 \mathrm{E}-01$ & $* 0.332 \mathrm{E}-01$ & $* 0.329 \mathrm{E}-01$ \\
\hline & 500000. & 0.104 & $0.214 \mathrm{E}-01$ & $0.203 \mathrm{E}-01$ & $0.204 \mathrm{E}-01$ & $* 0.409 \mathrm{E}-01$ & $* 0.398 \mathrm{E}-01$ \\
\hline $5 p{ }^{2} \mathrm{P}^{o}-6 \mathrm{~s}^{2} \mathrm{~S}$ & 20000 & $* 0.524$ & *_0.763E-02 & *0.345E-03 & $* 0.122 \mathrm{E}-02$ & *0.422E-03 & $* 0.740 \mathrm{E}-03$ \\
\hline $3 / 2-1 / 2$ & 50000 & 0.305 & $0.231 \mathrm{E}-01$ & $0.305 \mathrm{E}-02$ & $0.635 \mathrm{E}-02$ & $* 0.582 \mathrm{E}-02$ & $* 0.880 \mathrm{E}-02$ \\
\hline $481.0 \AA$ & 100000 & 0.220 & $0.224 \mathrm{E}-01$ & $0.840 \mathrm{E}-02$ & $0.117 \mathrm{E}-01$ & $* 0.167 \mathrm{E}-01$ & $* 0.203 \mathrm{E}-01$ \\
\hline \multirow[t]{3}{*}{$\mathrm{C}=0.96 \mathrm{E}+21$} & 200000 & 0.165 & $0.250 \mathrm{E}-01$ & $0.147 \mathrm{E}-01$ & $0.174 \mathrm{E}-01$ & $* 0.294 \mathrm{E}-01$ & $* 0.321 \mathrm{E}-01$ \\
\hline & 300000. & 0.143 & $0.261 \mathrm{E}-01$ & $0.192 \mathrm{E}-01$ & $0.201 \mathrm{E}-01$ & $* 0.384 \mathrm{E}-01$ & $* 0.379 \mathrm{E}-01$ \\
\hline & 500000 & 0.122 & $0.244 \mathrm{E}-01$ & $0.236 \mathrm{E}-01$ & $0.235 \mathrm{E}-01$ & *0.473E-01 & $* 0.458 \mathrm{E}-01$ \\
\hline $6 \mathrm{~s}^{2} \mathrm{~S}-6 \mathrm{p}{ }^{2} \mathrm{P}^{\circ}$ & 20000 & $* 13.5$ & $* 0.205$ & $* 0.560 \mathrm{E}-01$ & *-0.164E-01 & $* 0.484 \mathrm{E}-01$ & *_0.101E-01 \\
\hline $1 / 2-1 / 2$ & 50000. & 8.61 & -0.227 & 0.237 & $-0.896 \mathrm{E}-01$ & $* 0.401$ & $*_{-0.128}$ \\
\hline $2414.7 \AA$ & 100000. & 6.31 & -0.224 & 0.413 & -0.177 & $* 0.803$ & *-0.314 \\
\hline \multirow[t]{3}{*}{$\mathrm{C}=0.24 \mathrm{E}+23$} & 200000 & 4.81 & -0.296 & 0.591 & -0.268 & * 1.17 & $*_{-} 0.502$ \\
\hline & 300000. & 4.19 & -0.303 & 0.651 & -0.326 & $* 1.30$ & *-0.621 \\
\hline & 500000. & 3.60 & -0.281 & 0.733 & -0.378 & $* 1.46$ & *-0.739 \\
\hline
\end{tabular}


Table 1: Continued

\begin{tabular}{|c|c|c|c|c|c|c|c|}
\hline Transition & $\begin{array}{r}\mathrm{T} \\
{[\mathrm{K}]} \\
\end{array}$ & $\begin{array}{l}\mathrm{W}_{e} \\
{[\AA]} \\
\end{array}$ & $\begin{array}{r}\mathrm{d}_{e} \\
{[\AA]} \\
\end{array}$ & $\begin{array}{l}\mathrm{W}_{p} \\
{[\AA]} \\
\end{array}$ & $\begin{array}{r}\mathrm{d}_{p} \\
{[\AA]} \\
\end{array}$ & $\begin{array}{r}\mathrm{W}_{H e^{++}} \\
{[\AA]}\end{array}$ & $\begin{array}{r}\mathrm{d}_{H e^{++}} \\
{[\AA]}\end{array}$ \\
\hline $6 \mathrm{~s}^{2} \mathrm{~S}-6 \mathrm{p}{ }^{2} \mathrm{P}^{o}$ & 20000. & $* 10.7$ & $* 0.146$ & $* 0.470 \mathrm{E}-01$ & *-0.111E-01 & $* 0.403 \mathrm{E}-01$ & *-0.685E-02 \\
\hline $1 / 2-3 / 2$ & 50000. & 6.83 & -0.153 & 0.196 & $-0.610 \mathrm{E}-01$ & $* 0.330$ & *_0.872E-01 \\
\hline $2135.5 \AA$ & 100000. & 5.00 & -0.149 & 0.336 & -0.122 & $* 0.653$ & *-0.217 \\
\hline \multirow{3}{*}{$\mathrm{C}=0.19 \mathrm{E}+23$} & 200000 & 3.81 & -0.201 & 0.476 & -0.187 & $* 0.941$ & $*_{-} 0.351$ \\
\hline & 300000 . & 3.32 & -0.205 & 0.521 & -0.229 & * 1.04 & $*_{-} 0.438$ \\
\hline & 500000 & 2.86 & -0.190 & 0.582 & -0.267 & * 1.16 & $*_{-} 0.524$ \\
\hline \multicolumn{8}{|l|}{$\mathrm{N}=10^{20} \mathrm{~cm}^{-3}$} \\
\hline $5 \mathrm{p}^{2} \mathrm{P}^{\mathrm{o}}-6 \mathrm{~s}^{2} \mathrm{~S}$ & 20000. & & & & & & \\
\hline $1 / 2-1 / 2$ & 50000. & $*_{2.61}$ & $* 0.141$ & $* 0.235 \mathrm{E}-01$ & $* 0.262 \mathrm{E}-01$ & & \\
\hline $447.5 \AA$ & 100000 & 1.88 & 0.159 & $* 0.712 \mathrm{E}-01$ & $* 0.730 \mathrm{E}-01$ & & \\
\hline \multirow[t]{3}{*}{$\mathrm{C}=0.83 \mathrm{E}+22$} & 200000 & 1.41 & 0.193 & $* 0.127$ & $* 0.126$ & & \\
\hline & 300000 . & 1.22 & 0.208 & $* 0.165$ & $* 0.152$ & & \\
\hline & 500000 & 1.04 & 0.197 & $* 0.203$ & $* 0.194$ & & \\
\hline $5 p^{2} \mathrm{P}^{o}-6 \mathrm{~s}^{2} \mathrm{~S}$ & 20000. & & & & & & \\
\hline $3 / 2-1 / 2$ & 50000. & $* 3.05$ & $* 0.160$ & $* 0.275 \mathrm{E}-01$ & $* 0.302 \mathrm{E}-01$ & & \\
\hline $481.0 \AA$ & 100000 . & 2.20 & 0.180 & $*_{0.828 \mathrm{E}-01}$ & $* 0.841 \mathrm{E}-01$ & & \\
\hline \multirow[t]{3}{*}{$\mathrm{C}=0.96 \mathrm{E}+22$} & 200000 . & 1.65 & 0.220 & $* 0.147$ & $* 0.145$ & & \\
\hline & 300000 . & 1.43 & 0.238 & $* 0.191$ & $* 0.175$ & & \\
\hline & 500000 & 1.22 & 0.224 & $* 0.235$ & $* 0.223$ & & \\
\hline
\end{tabular}


Table 1: Continued

\begin{tabular}{|c|c|c|c|c|c|c|c|}
\hline \multirow[t]{2}{*}{ Transition } & $\mathrm{T}$ & $\mathrm{W}_{e}$ & $\mathrm{~d}_{e}$ & $\mathrm{~W}_{p}$ & $\mathrm{~d}_{p}$ & $\mathrm{~W}_{\mathrm{He}^{++}}$ & $\mathrm{d}_{H e^{++}}$ \\
\hline & {$[\mathrm{K}]$} & {$[\AA]$} & {$[\AA]$} & {$[\AA]$} & {$[\AA]$} & {$[\AA]$} & {$[\AA]$} \\
\hline $6 \mathrm{~s}^{2} \mathrm{~S}-6 \mathrm{p}{ }^{2} \mathrm{P}^{o}$ & 20000 & & & & & & \\
\hline $1 / 2-1 / 2$ & 50000 & $* 86.1$ & $*_{-} 1.34$ & $* 1.69$ & $*_{-} 0.456$ & & \\
\hline $2414.7 \AA$ & 100000 & $* 63.1$ & $*_{-} 1.66$ & $* 3.82$ & $*-1.34$ & & \\
\hline \multirow[t]{3}{*}{$\mathrm{C}=0.24 \mathrm{E}+24$} & 200000 . & 48.1 & -2.57 & $*_{5.74}$ & * -2.31 & & \\
\hline & 300000 . & 41.9 & -2.72 & $*^{*} 6.44$ & * -2.91 & & \\
\hline & 500000 & 36.0 & -2.55 & $* 7.30$ & $*-3.62$ & & \\
\hline $6 s{ }^{2} \mathrm{~S}-6 \mathrm{p}{ }^{2} \mathrm{P}^{o}$ & 20000. & & & & & & \\
\hline $1 / 2-3 / 2$ & 50000 & ${ }^{*} 68.2$ & *-0.906 & $* 1.38$ & $*_{-0} 0.314$ & & \\
\hline $2135.5 \AA$ & 100000 . & $* 50.0$ & $*-1.10$ & $* 3.10$ & *-0.930 & & \\
\hline \multirow[t]{3}{*}{$\mathrm{C}=0.19 \mathrm{E}+24$} & 200000 & 38.1 & -1.75 & $* 4.61$ & $*-1.62$ & & \\
\hline & 300000 . & 33.2 & -1.84 & $*_{5} 5.14$ & $*-2.05$ & & \\
\hline & 500000 & 28.6 & -1.73 & $*^{*} 5.80$ & $*-2.57$ & & \\
\hline \multicolumn{8}{|l|}{$\mathrm{N}=10^{21} \mathrm{~cm}^{-3}$} \\
\hline $5 p{ }^{2} \mathrm{P}^{o}-6 \mathrm{~s}^{2} \mathrm{~S}$ & 20000. & & & & & & \\
\hline $1 / 2-1 / 2$ & 50000 & & & & & & \\
\hline $447.5 \AA$ & 100000 . & & & & & & \\
\hline \multirow[t]{3}{*}{$\mathrm{C}=0.83 \mathrm{E}+23$} & 200000 & $* 14.0$ & *0.992 & & & & \\
\hline & 300000 . & *12.1 & * 1.34 & & & & \\
\hline & 500000 & *10.3 & * 1.42 & & & & \\
\hline
\end{tabular}


Table 1: Continued

\begin{tabular}{crrrrrrr}
\hline Transition & $\mathrm{T}$ & $\mathrm{W}_{e}$ & $\mathrm{~d}_{e}$ & $\mathrm{~W}_{p}$ & $\mathrm{~d}_{p}$ & $\mathrm{~W}_{H e^{++}}$ & $\mathrm{d}_{H e^{++}}$ \\
& {$[\mathrm{K}]$} & {$[\AA]$} & {$[\AA]$} & {$[\AA]$} & {$[\AA]$} & {$[\AA]$} & {$[\AA]$} \\
\hline $5 \mathrm{p}{ }^{2} \mathrm{P}^{\mathrm{o}}-6 \mathrm{~s}^{2} \mathrm{~S}$ & 20000. & & & & & & \\
& 50000. & & & & & & \\
$481.0 \AA$ & 100000. & & & & & & \\
$\mathrm{C}=0.96 \mathrm{E}+23$ & 200000. & $* 16.4$ & $* 1.12$ & & & \\
& 300000. & $* 14.2$ & $* 1.52$ & & \\
& 500000. & $* 12.1$ & $* 1.62$ & & \\
\hline
\end{tabular}




\section{REFERENCES}

Bates D. R., Damgaard A. 1949, Philos. Trans. R. Soc. London A, 242, 101.

Biémont, É., Buchard, V., Garnir, H.-P., Lefèbvre, Quinet, P. 2005, Eur. Phys. J. D, 33, 181

Churilov, S. S., Joshi, Y. N. 2000, Phys. Scr., 62, 358

Cowley, C. R. 1971, Observatory, 91, 139

Dimitrijević M. S., Sahal-Bréchot S. 1994, Phys. Scripta, 49, 661.

Dimitrijević M. S., Kovačević A., Simić Z., Sahal-Bréchot S. 2011, Baltic Astron., 20, 580.

Dreizler S., Werner K. 1996, A\&A, 314, 217.

Dubernet M. L., Boudon V., Culhane J. L., Dimitrijević M. S., Fazliev A. Z. et al. 2010, J. Quant. Spectrosc. Radiat. Transfer, 111, 2151, http://www.vamdc.org

Dufour P., Ben Nessib N., Sahal-Bréchot S., Dimitrijević M. S. 2011, Baltic Astron., 20, 511.

Fontaine, M., Chayer, P., Oliveira, C. M. et al. 2008, ApJ, 678, 394.

Gallardo, M., Raineri, M., Reyna Almandos, J., Pagan, C. J. B., Abrahão, R. A. 2015, ApJS, 216, 11

Grabowski, B., Madej, J., Halenka, J. 1987, ApJ, 313, 750.

Hamdi R., Ben Nessib N., Milovanović N., Popović L. Č., Dimitrijević M. S., Sahal-Bréchot S. 2008, MNRAS, 387, 871 .

Hamdi, R., Ben Nessib, N., Sahal-Brchot, S., Dimitrijevi, M. S. 2014, Adv. Space Res., 54, 1223. 
Kaufman, V., Sugar, J. 1987, J. Opt. Soc. Am. B, 4, 1924

Koester, D. 2010, Mem. Soc. Astron. Italiana, 81, 921.

Kondo K., Nakajima M., Kawamura T., Horioka K. 2008, The fifth International Conference on Inertial Fusion Sciences and Applications, J. Phys: Conf. Series, 112, 042028.

Kondo K., Nakajima M., Kawamura T., Horioka K. 2009, Nuclear Instruments and Methods in Physics Research A, 606, 223.

Larbi-Terzi N., Sahal-Bréchot S., Ben Nessib N., Dimitrijević M. S. 2012, MNRAS, 423, 766.

Larsson, M. O., Gonzalez, A. M., Hallin, R., Heijkenskjöld, F., Nyström, B., O’Sullivan, G., Weber, C., Wännström, A. 1996, Phys. Scr., 53, 317

Milovanović N., Dimitrijević M. S., Popović L. Č., Simić, Z. 2004, A\&̋A, 417, 375.

Oertel G. K., Shomo L. P. 1968, ApJS, 16, 175.

Popović L. Č., Dimitrijević M. S., Tankosić D. 1999, AछAS, 139, 617.

Puetter, R. C. 1981, ApJ, 251, 446.

Rauch, T., Hoyer, D., Quinet, P., Gallardo, M., Raineri, M. 2015, AøA, 577, A88

Rixon G., Dubernet M. L., Piskunov, N., Walton, N., Mason, N. et al. $20117^{\text {th }}$ International Conference on Atomic and Molecular Data and their Applications -ICAMDATA-2010, AIP Conf. Proc., 1344, 107.

Ryutov D. D., Drake R. P., Kane J., Liang E., Remington B. A., Wood-Vasey W. M. 1999, ApJ, 518, 821 .

Sahal-Bréchot S. 1969a, A\&GA, 1, 91. 
Sahal-Bréchot S. 1969b, A\&A, 2, 322.

Sahal-Bréchot S., Dimitrijević M. S., Ben Nessib N. 2014, Atoms, 2, 225.

Sahal-Bréchot S., Dimitrijević M. S., Moreau N. 2015a, STARK-B database, [online]. Available: http://stark-b.obspm.fr [June 19, 2015]. Observatory of Paris, LERMA and Astronomical Observatory of Belgrade.

Sahal-Bréchot S., Dimitrijević M. S., Moreau N., Ben Nessib N. 2015b, Phys. Scripta, 50, 054008 .

Saloman E. B. 2004, J. Phys. Chem. Ref. Data, 33, 765.

Schmidt, G. D., West, S. C., Liebert, J., Green, R. F., Stockman, H. S. 1986, ApJ, 309, 218.

Simić Z., Dimitrijević M. S., Popović L. Č., Dačić M. 2006, New Astron., 12, 187.

Simić Z., Dimitrijević M. S., Sahal-Bréchot S. 2013, MNRAS, 432, 2247.

Simić Z., Dimitrijević M. S., Popović L. Č. 2014a, Adv. Space Res., 54, 1231.

Simić, Z., Dimitrijević, M. S., Popović, L.Č. 2014b, New Astron., 12, 187.

Tankosić D., Popović L. Č., Dimitrijević M. S. 2003, A\&A, 399, 795.

Tauheed, A., Joshi, Y. N., Pinnington, E. H. 1992, J. Phys. B, 25, L561.

Tremblay, P. E., Bergeron, P. 2009, ApJ, 696, 1755.

Wang, M., Larsson, M. O., Arnesen, A., Hallin, R., Heijkenskjöld, F., Nordling, C., Wännström, A. 1996, J. Opt. Soc. Am. B, 13, 2715 (Erratum: 1997, J. Opt. Soc. Am. B, 14, 1515). 
Wang, M., Arnesen, A., Hallin, R., Heijkenskjöld, F., Larsson, M. O., Wännström, A., Trigueiros, A.G., Loginov, A. V. 1997, J. Opt. Soc. Am. B, 14, 3277.

Werner, K., Heber, U., Hunger, R. 1991, A\&A, 244, 437.

Werner K., Rauch Th., Ringat E., Kruk J. W. 2012, ApJL, 753, L7.

Wickramasinghe, D.T. 1972,Mem. R. Astron. Soc., 76, 129.

Ziegler, M., Rauch, T., Werner, K., Köpen, J., Kruk, J. W. 2012, Aध̈A, 548, A109 